\title{
HUMAN SMALL CELL LUNG CANCER CELL LINE (NCI-H146) TUMOR BEHAVIOUR ON THE CHICKEN EMBRYO CHORIOALLANTOIC MEMBRANE AFTER THE SODIUM VALPROATE TREATMENT
}

\author{
Lina Šlekienė, Raminta Mozūraitė, Ruta Vosyliūtė, \\ INGRIDA BALNYTÉ, ANgelija VAlanČiŪté \\ Department of Histology and Embryology, \\ Lithuanian University of Health Sciences, Kaunas, Lithuania
}

\begin{abstract}
Small cell lung cancer (SCLC) is an aggressive form of cancer with 5-year survival rate and poor prognosis. Since patients' initial response to therapy is rapidly followed by a relapse with the drug-resistant disease, new therapies are required. The aim was to evaluate whether H146 cell line tumor was able to maintain the morphological pattern when grafted on the chicken embryo chorioallantoic membrane (CAM). Also, to evaluate the morphological changes in the CAM after grafting the tumor without or with treatment with sodium valproate (NaVP). The cell culture of the commercial NCIH146 cell line was used for the formation of the tumor. The tumor of $1 \times 10^{6}$ cells and I type rat tail collagen was dropped onto the absordable sponge and instantly grafted on CAM. After 5 days of incubation chicken embryos were sacrificed and CAMs were cut out. Standard H\&E staining and immunohistochemistry (CD56) were performed. The histomorphometrical analysis of non-treated $(n=5), 4 \mathrm{mM} \mathrm{NaVP}$-treated $(\mathrm{n}=5)$ and $8 \mathrm{mM}(\mathrm{n}=5)$ of NaVPtreated groups was performed. The thickness of the CAM was measured in all the investigated groups in the areas under the onplant and in the neighbouring sites. H146 cells are able to maintain morphological appearance on the CAM and retained the expression of specific profile for CD56. H146 cell tumor increased the thickness of the CAM under the tumor in the nontreated group $(509.2 \pm 184 \mu \mathrm{m})$. After treatment with $4 \mathrm{mM}$ and $8 \mathrm{mM}$ of NaVP CAM thickness decreased $(362 \pm 232.6 \mu \mathrm{m}$ and $147.8 \pm 98.4 \mu \mathrm{m}$ respectively; $\mathrm{p}<0.0001)$. The effect of $\mathrm{NaVP}$ on CAM increased with increasing solution
\end{abstract}


concentrations of $4 \mathrm{mM}$ and $8 \mathrm{mM}$. CAM thickness in the non-treated group neighbouring to the tumor site was $139.1 \pm 138.4 \mu \mathrm{m}$, in $4 \mathrm{mM} \mathrm{NaVP}$-treated group - 104.9 $\pm 81 \mu \mathrm{m}$ and in $8 \mathrm{mM} \mathrm{NaVP}$-treated group CAM thickness reached only $70.8 \pm 51.5 \mu \mathrm{m}$. CAM thickness in the non-treated group significantly differs compared to $4 \mathrm{mM}$ and $8 \mathrm{mM}$ of $\mathrm{NaVP}$ - the treated groups $(\mathrm{p}<0.05, \mathrm{p}<0.0001)$. Difference between both NaVP-treated groups is also significant $(\mathrm{p}<0.05)$. CAM is a suitable model for in vivo analysis of human H146 cell line formed tumor. Cells grafted on the CAM preserved their morphology and expressed characteristic immunohistochemical markers. CAM mesenchyme proliferation was suppressed under the influence of NaVP in concentration-dependent manner.

Key words: chicken embryo; chorioallantoic membrane; small cell lung cancer; sodium valproate

\section{INTRODUCTION}

Lung cancer, including small cell lung cancer (SCLC), is a leading cause of cancer related death, both in the USA and worldwide. SCLC composes 16\% of all lung cancers and causes significant morbidity and mortality worldwide. It tends to metastasize outside the chest two-thirds of the time at clinical presentation, and approximately only $7 \%$ of patients are alive for 5 years since the beginning of treatment [20]. Recently, new agents such as erlotinib and bevacizuman, have been approved for the treatment of lung cancer, however the 5 -year survival rate reaching $16 \%$ still remains the same [6]. On the contrary to other agents targeting single gene product, epigenetic drugs have chromatin as their target through the inhibition of histone deacetylases (HDAC'S) and DNA methyltransferases (DNMT'S) therefore, they may act upon most or all tumor types [4]. Because small cell lung carcinomas are reffered as neuroendocrine malignancy [17], for these reasons in our study we used MAb 123C3 for the immunohistochemical staining of SCLC which was tested on paraffin sections. CD56 or neural cell adhesion molecule (NCAM) comprises a family of cell surface sialoglycoproteins of the immunoglobulin superfamily. NCAM is expressed mainly in natural killer (NK) cells, NK-like T cells, neuroectodermal/neuroendocrine tissues, and their corresponding neoplasms [7].

Valproic acid sodium salt (NaVP), a well-known anticonvulsive agent, in 1997 emerged as an antineoplastic agent as well, when findings suggested the substance being able to inhibit proliferation and induced the differentiation 
of primitive neuroectodermal tumor cells in vivo [1]. In particular valproic acid is an inhibitor of HDAC's displaying appropriate pharmacokinetic properties, and yielding only moderate toxicity that is acceptable in the context of an anticancer treatment [5]. Nowadays NaVP approaches an increasing interest. Several studies have shown antitumoral activities, as well as anti-angiogenic properties of $\mathrm{NaVP}$, either alone or in combination with standard anticancer treatment $[2,5,10-11,14-15,18,22]$.

Since dose-response determination, toxicity and schedule (i.e. doses, timing) require a substantial number of animals, the chick embryo chorioallantoic membrane (CAM) model is used in the pharmaceutical research for the evaluation of drug delivery systems, as well as tumor growth and metastasis. Histologically the CAM consists of two epithelial sheets that limit a thin layer of stroma. The highly vascularized network of the CAM sustains tumor viability, which have been shown to engraft and follow all the steps of tumor progression: growth, angiogenesis, invasion, extravasation and metastasis $[3,21]$. This alternate model suggests that primary xenografts models may represent a better platform for preclinical therapeutic testing.

We investigated the capacity of SCLC cell line NCI-H146 to maintain its proliferative and metastatic capacity in vivo, the ability to form a solid tumor on CAM while being affected with concentrations of either $4 \mathrm{mM}$ or $8 \mathrm{mM}$ of $\mathrm{NaVP}$ compared to non-NaVP-treated group. We evaluated whether NCI-H146 cells are able to retain their original morphological characteristic when grafted on the CAM including the ability to penetrate the deeper layers of the CAM under the influence of valproic acid and the thickness of the CAM after the malignant cell transplant of the tumor which was not treated with NaVP and tumors which was treated with increasing doses of NaVP.

\section{MATERIAL AND METHODS}

Cell culture. Human SCLC NCI-H146 cells were obtained from the State Research Institute Centre for Innovative Medicine (Vilnius, Lithuania). The H146 cells were maintained in RPMI 1640 medium supplemented with $4.5 \mathrm{~g} / \mathrm{L}$ glucose, $2 \mathrm{mM}$ L-glutamine, sodium pyruvate, HEPES and contained 10\% heat-inactivated FBS, $100 \mathrm{U} / \mathrm{ml}$ penicillin and $100 \mu \mathrm{g} / \mathrm{ml}$ streptomycin were also added. Cells were grown at $37^{\circ} \mathrm{C}$ in a humidified atmosphere of $95 \%$ air and $5 \% \mathrm{CO}_{2}$. 
Tumor xenograft model. Cells were mixed with the solution of concentration equivalent to $4 \mathrm{mM}$ and $8 \mathrm{mM}$ of NaVP (SigmaAldrich; Merck KGaA) and type I rat tail collagen (GIBCO, USA) to a final concentration of $1 \times 10^{6}$ cells $/ 20 \mu \mathrm{l}$. Tumors without NaVP, were formed only of H146 cells and type I rat tail collagen in a total volume of $20 \mu \mathrm{l}$ containing the same amount of cells. NaVP was dissolved in the serum-free RPMI-1640 medium. $20 \mu$ of liquefied tumor was pipetted on an absordable sponge. Formed tumor was then placed on a CAM between a major blood vessels. Tumors were further visualized under the stereomicroscope (SZX16, Olympus, Japan) from the $2^{\text {nd }}$ to the $5^{\text {th }}$ day of tumor grafting $\left(9^{\text {th }}-12^{\text {th }}\right.$ day of embryo day development (EDD)) consecutively.

Preparation of the CAM. Fertilized Cobb 500 chicken eggs from a local hatchery were transferred into a hatching incubator (Maino Enrico, $0084 \mathrm{AXH}$, Oltrona, Italy). Relative air humidity was set of $60 \%$ and a temperature of $37^{\circ} \mathrm{C}$. Eggs were automatically rotated until EDD 3. On EDD 3 a small hole at the air chamber was drilled and approximately $2 \mathrm{ml}$ of albumin was removed. Then a window of approximately $1 \mathrm{~cm}$ in diameter was opened in the eggshell and covered with a sterile transparent tape. The eggs were then returned to the incubator and kept until harvesting the CAM.

CAM sampling. On EDD 12 chick embryos were sacrificied, the CAMs of all the investigated groups were cut out and embedded into paraffin, followed with further serial sectioning using LEICA RM 2155 microtome (Leica Microsystems, Inc., Buffalo Grove, IL, USA).

\section{Hematoxylin-Eosin staining, cytological staining and immunohistochemistry} (IHC) with CD56. Standard hematoxylin and eosin (H\&E) staining was performed. Cytological staining was performed using the standard cytological smear technique. Cells were stained using Diff-Quik ${ }^{\circledR}$ Solutions (Medion Diagnostics, Dade Behring Inc.) by consecutive brief immersions for 5 seconds in each solution. Firstly cells were fixed in methanol, then counterstained with Thiazine dye and Eosin Y. For immunohistocemistry tissue slides were placed in xylene, then into the ethanol of graded series (70\%, 80\% and 90\%). Epitope retrieval was performed using a high $\mathrm{pH}$ epitope retrieval solution (Dako, USA) in a pressure cooker $\left(110^{\circ} \mathrm{C}\right.$ for 3 minutes). Peroxidase blocking solution (Dako REAL ${ }^{\mathrm{rm}}$, Dako, USA) was added followed by 20 wash buffer (Dako, USA). Then the primary antibody solution (mouse Anti-CD56, 1:100, 
clone: 123C3, Life Technologies, USA) was added for $1 \mathrm{~h}$ at room temperature. Afterwards the secondary antibody was added (EnVision ${ }^{\text {tw }}$ FLEX+ MOUSE (LINKER), Dako, USA) which was followed by the FLEX/HRP (EnVision ${ }^{\text {tm }}$ FLEX/HRP, Dako), both with incubation for 30 minutes at room temperature. Later, 3.3'diaminobenzidine chromogen (Dako) was added. Finally slides were counterstained using Mayers's hematoxylin and covered with cover slides using mounting media (Roti HistoKit).

Histomorphometric analysis of the CAM. Thickness of the CAM was measured using an Olympus BX 40F4 microscope (Olympus Corporation, Tokyo, Japan) equipped with the XC30 digital camera (Olympus Corporation). A magnification of $\mathrm{x} 4$ was used to evaluate the thickness of CAM under the onplant in a constant length of all the investigated groups. The histomorphometric analysis was performed using the CellSens Dimension 2010 software (version 1.3; Olympus Corporation).

Statistical analysis. Data are presented as mean \pm SD. Statistical significance was calculated using the analysis of variance One-Way Anova using IBM SPSS statistics 23 . Data were considered statistically significant when $p<0.05$ or highly statistically significant when $\mathrm{p}<0.0001$.

\section{RESULTS}

H146 cell tumor retained its morphological characteristics and SCLC specific CD56 expression after grafting on the CAM. The Histological analysis of hematoxylin and eosin staining of H146 cell line tumor formed on CAM revealed retained mitotic activity in vivo of SCLC compared to in vitro with enhanced metastasis into CAM's mesenchyme layer. H146 cells are proved to be highly proliferative (mitotic cells, figure $1, \mathrm{~A}$, arrows) and are seen migrating away from the main part of the tumor. Mitotic figures were also noticed in the cytological smears of H146 cell line (Figure 1, A). Immunohistochemical staining of SCLC xenografts used in this study revealed maintained consistent expression of CD56 (Figure 2). Furthermore our results show a tumor which by its histologic features and tumor marker expression profiles closely resembles the parental tumor described by Kaufmann et al. [7]. SCLC tumor without $\mathrm{NaVP}$ treatment invading the mesenchyme is seen in Figure 2, where two main fields can be distinguished (Figure 2, B and C). The expression of CD56 in the 
H146 cells appearing at the border of tumor and CAM's mesenchyme became much more prominent (Figure 2, C) than the cells existing at the periphery of the tumor (Figure 2, B) which cytoplasm failed to retain the high expression of CD56. This result indicates the malignancy of SCLC cells and the need of nutrient supply for the tumor from the existing blood vessels in the mesenchyme layer. Migrating cells from the main part of the tumor to the mesenchyme are labelled by CD56 (Figure 2, D - arrows).

\section{Valproic acid reduces thickness of the CAM at the site of H146 cell tumor} implantation. The thickness of the CAM was assessed in each group of nontreated $(\mathrm{n}=5), 4 \mathrm{mM}$ NaVP-treated $(\mathrm{n}=5)$ and $8 \mathrm{mM} \mathrm{NaVP}$-treated $(\mathrm{n}=5)$ tumors at the site of implantation and in the neighbouring sites. Statistically significant results were noticed in the non-treated group compared to $4 \mathrm{mM}$ NaVP-treated group $(\mathrm{p}<0.0001)$, where CAM thickness was reduced by $29 \%$, while comparing the non-treated group. In $8 \mathrm{mM} \mathrm{NaVP-treated} \mathrm{group} \mathrm{CAM}$ thickness was significantly reduced even by $72 \%(\mathrm{p}<0.0001)$. Statistically significant results were also noticed between both treated groups of $4 \mathrm{mM}$ and $8 \mathrm{mM}$ of NaVP $(\mathrm{p}=0.002)$, where CAM thickness was reduced by $60 \%$ (Figure 3). The thickness of the CAM in non-treated, $4 \mathrm{mM} \mathrm{NaVP}$-treated and $8 \mathrm{mM} \mathrm{NaVP}$-treated are $509.2 \pm 184 \mu \mathrm{m}, 362 \pm 232.6 \mu \mathrm{m}$ and $147.8 \pm 98.4 \mu \mathrm{m}$ respectively.

Valproic acid reduces thickness of the CAM at the neighbouring site of H146 cell tumor implantation. CAM thickness in the neighbouring sites away from the onplant in non-treated group is $139.1 \pm 138.4 \mu \mathrm{m}$, in $4 \mathrm{mM} \mathrm{NaVP}$-treated group $104.9 \pm 81 \mu \mathrm{m}$ and in the $8 \mathrm{mM} \mathrm{NaVP}$-treated group CAM thickness is only $70.8 \pm 51.5 \mu \mathrm{m}$. When comparing the non-treated group with $4 \mathrm{mM} \mathrm{NaVP}$ treated group statistical significance is noticed $(\mathrm{p}<0.05)$, comparing groups of non-treated and of $8 \mathrm{mM} \mathrm{NaVP}$-treated statistical significance increases $(\mathrm{p}<0.0001)$ and the difference between each NaVP-treated group of $4 \mathrm{mM}$ and $8 \mathrm{mM}$ is significant $(\mathrm{p}<0.05$, Figure 4$)$.

Evaluation of Hematoxylin-Eosin stained H146 cell tumors on the CAMs. Figure 5 represents histological sections of all investigated groups - H146 tumors without treatment (Figures $5 \mathrm{~A}$ and $5 \mathrm{~B}$ ), tumor with $4 \mathrm{mM} \mathrm{NaVP}$ treated cells (Figure 5C), tumor of $8 \mathrm{mM} \mathrm{NaVP}$-treated cells (Figure 5D). The highly vascularized tumor of large size of the non-treated group is shown in 


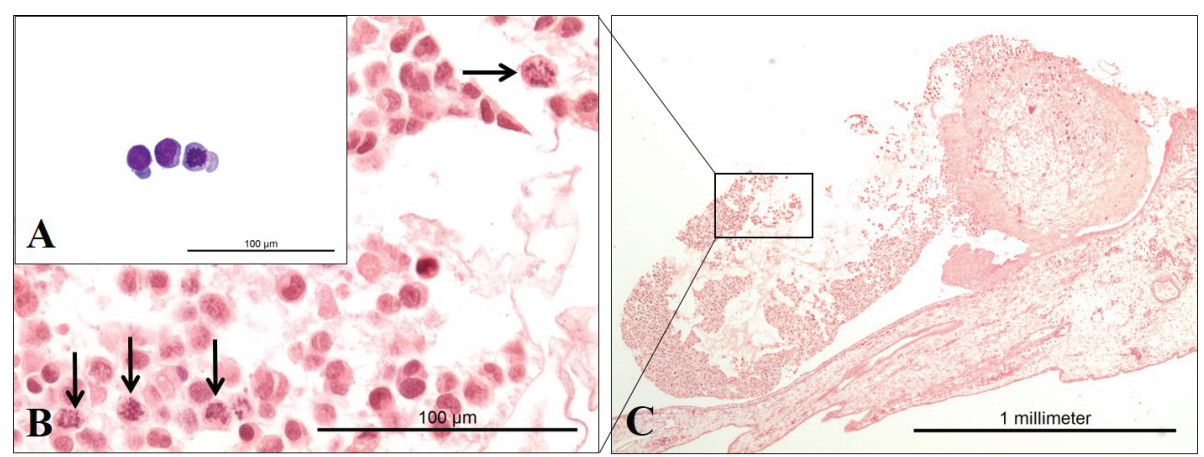

Figure 1. H146 cells in cytological smear and in tumor formed on the CAM. Tumor of CAM on EDD 12 without treatment showing mitotically active $\mathrm{H} 146$ cells in histological section (B - arrows, C) likewise in cytological smear (A). Scale bar - $100 \mu \mathrm{m}$ ( $A$ and $B$ ). Scale bar $-1 \mathrm{~mm}(\mathrm{C})$.
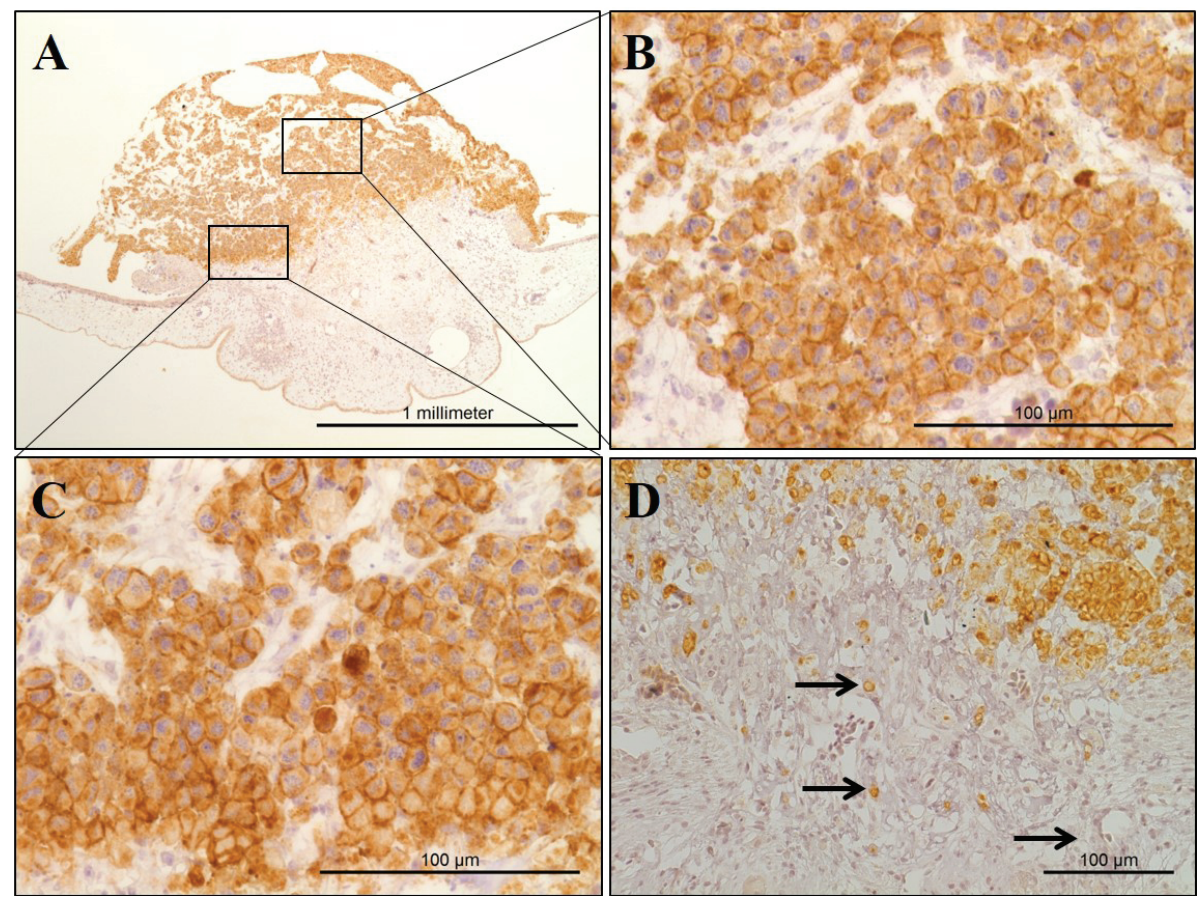

Figure 2. Migrating SCLC cells into the mesenchyme of the CAM. H146 cells show the expression of the neuroendocrine marker CD56 (A, B, C and D). The expression of CD56 in $\mathrm{H} 146$ cells closer to the mesenchyme is higher (C) than those at the top of the tumor (B). The migrating cells escape from the main tumor area and metastatised deeper into the mesenchyme, $\mathrm{H} 146$ are labelled by arrows (D). Scale bar $-1 \mathrm{~mm}(\mathrm{~A}), 100 \mu \mathrm{m}$ (B, C and D). 


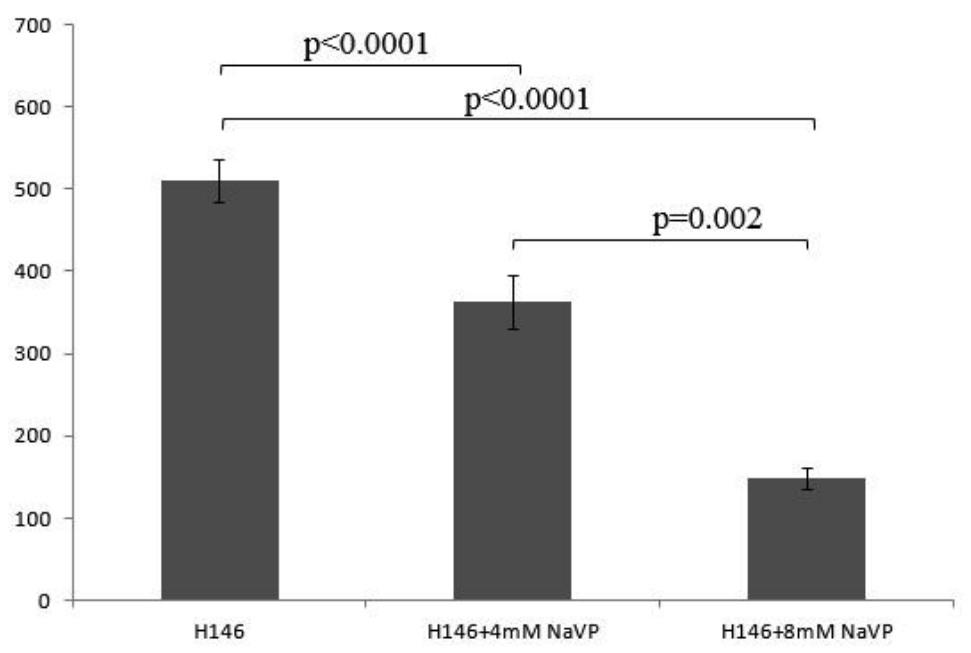

Figure 3. CAM thickness under non-treated and $4 \mathrm{mM}$ and $8 \mathrm{mM}$ NaVP-treated tumors. CAM thickness (in $\mu \mathrm{m}$ ) is highly reduced in $4 \mathrm{mM}$ and $8 \mathrm{mM}$ of NaVP solution treated tumors when comparing to non-treated $\mathrm{H} 146$ cell tumors.

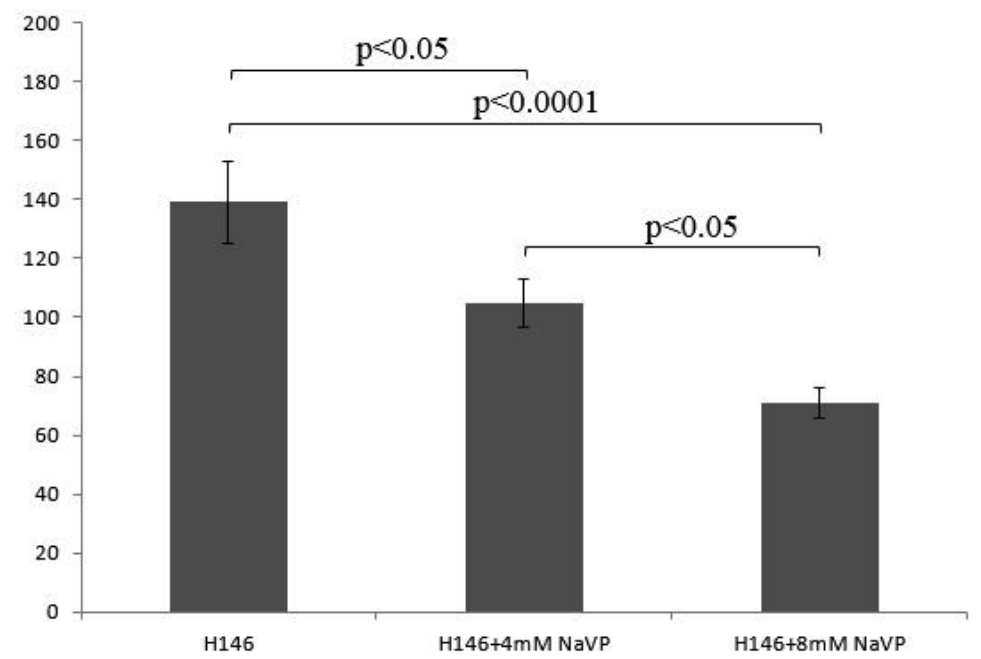

Figure 4. CAM thickness in the neighbouring area to non-treated and $4 \mathrm{mM}$ and $8 \mathrm{mM}$ NaVP-treated tumors. CAM thickness (in $\mu \mathrm{m}$ ) is highly reduced in $4 \mathrm{mM}$ and $8 \mathrm{mM}$ of NaVP solution treated tumors when comparing to non-treated $\mathrm{H} 146$ cell tumors. 

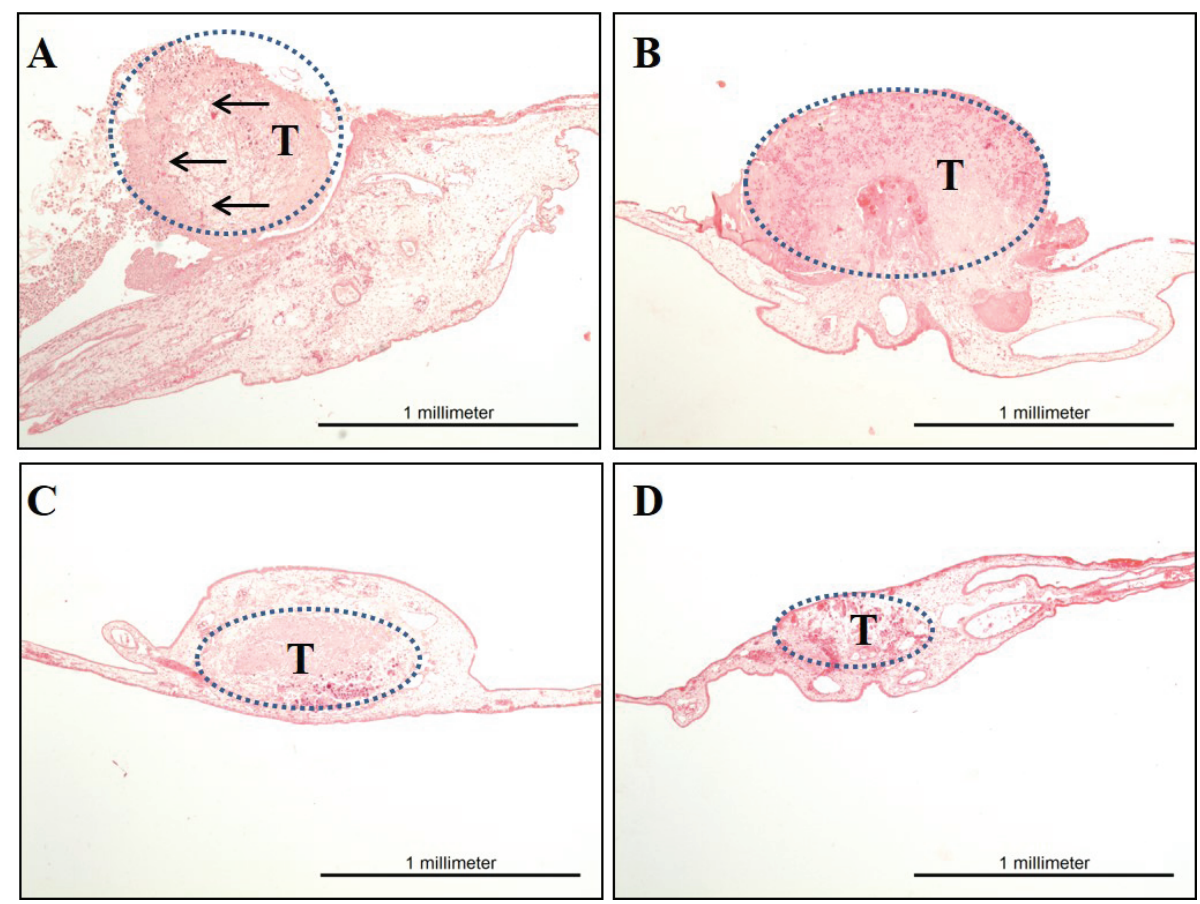

Figure 5. Hematoxylin and Eosin staining of CAMs with non-treated and $4 \mathrm{mM}$ and $8 \mathrm{mM}$ NaVP-treated tumors on EDD 12. CAM with tumor made of non-treated cells ( $A$ and $B$ ) contains large amount of blood vessels in the tumour tissue (A, arrows), CAM is thickened under the tumor. $C$ and $D$ represents tumors on the CAMs made of $4 \mathrm{mM}$ and $8 \mathrm{mM}$ NaVP-treated cells respectively. Decreased tumor volume is encircled with a dashed line $(T)$. Scale bar $-1 \mathrm{~mm}$.

Figures 5A and 5B, numerous small blood vessels are labelled with arrows. In Figure 5C CAM with tumor made of $4 \mathrm{mM} \mathrm{NaVP-treated} \mathrm{cells} \mathrm{is} \mathrm{shown} \mathrm{with} \mathrm{a}$ notably lower amount of neoplastic tissue and slightly reduced thickness of the CAM, while Figure 5D represents CAM with the tumor made of $8 \mathrm{mM} \mathrm{NaVP-}$ treated cells with much more reduced thickness of CAM and reduced mass of tumor inside the mesenchyme.

\section{DISCUSSION}

For a long time, the CAM has been used for the study of tumor growth and metastasis because the chick's immune system is not fully developed untill EDD 18 and the conditions for rejection have not been yet established [16]. Korngold and Lipari demonstrated that the human tumor transplanted and 
re-transplanted on CAM retain and express human antigens after several passages [8]. Our study confirmed this statement. We developed an experimental tumor model for the human SCLC cell line (NCI-H146) and demonstrated that the human SCLC cells implanted on the CAM formed vascularized tumors within 5 days. Tumor cells highly expressed markers specific for SCLC especially at the tumor implantation site. Drug delivery systems (DDS) are often studied in vitro with cells in culture and then tested in pre-clinical animal models [19]. However, a leap from in vitro studies with cells to in vivo preclinical animal models usually leads to unsatisfactory results due to the high cost of the pre-clinical studies. Thus the CAM has been used as an excellent platform to test multiple DDS formulations as an intermediate step between in vitro analysis and in vivo preclinical evaluation in mammals [12]. The tumors affected with NaVP resulted in a highly decreased CAM thickness under the implantation site compared to the non-treated group as well as in the neighbouring sites away from the main tumor tissue. The cells formed of treated with $\mathrm{NaVP}$ cells formed smaller tumors as well. Previous studies have shown in vitro effect of NaVP on the other SCLC cell line DMS53, when treatment with NaVP concentrations as low as $1 \mathrm{mM}$ significantly impaired the cell mitochondrial activity, while higher concentrations $(6 \mathrm{mM}-10 \mathrm{mM})$ of NaVP resulted in the absence of tumor markers [15]. Similar results have been shown testing valproic acid on different tumor cell lines other than SCLC. Masatoshi and co-authors showed a potential usefulness of NaVP in combination with radiotherapy for treating oesophageal cancer [18]. Nowak-Sliwinska with collaborators tested the effect of minimally invasive PDT (photodynamic therapy) that can potentially destroy the unwanted neoplastic tissue while sparing the neighbouring normal tissue. It was noted that the PDT treatment induces wounding of the CAM tissue leading to a thinner membrane as compared to the untreated area [13]. Likewise our results show, CAM thickening was also seen in the prostate cancer cell inoculation [9]. Thus our findings correlate with the results of other authors described above, indicating that NaVP changes proliferation of cancer cells grafted on CAM further changing its morphologic appearance by decreasing the thickness at the site of onplant. In this well vascularized chorioallantoic membrane, the versatile system for in vivo cancer research, we achieved highly reliable differences in the thickness of the CAM of non-treated and NaVP-treated SCLC-CAM groups, possibly showing the anti-tumor and anti-angiogenic effect keeping cancer cells from active proliferation. 


\section{REFERENCES}

1. Blaheta R.A., Michaelis M., Driever P.H., Cinatl J. Jr. (2005). Evolving anticancer drug valproic acid: insights into the mechanism and clinical studies. Med Res Rev, 25, 4, 383-397. https://doi.org/10.1002/med.20027

2. Catalano M.G., Fortunati N., Pugliese M., Costantino L., Poli R., Bosco O., Boccuzzi G. (2005). Valproic acid induces apoptosis and cell cycle arrest in poorly differentiated thyroid cancer cells. J Clin Endocrinol Metab, 90, 3, 1383-1389. https://doi.org/10.1210/jc.2004-1355

3. Deryugina E.I., Quigley J.P. (2008). Chick embryo chorioallantoic membrane model systems to study and visualize human tumor cell metastasis. Histochem Cell Biol, 130, 6, 1119-1130. https://doi.org/10.1007/s00418-008-0536-2

4. Duenas-Gonzalez A, Candelaria M., Perez-Plascencia C., Perez-Cardenas E., de la Cruz-Hernandez E., Herrera L.A. (2008). Valproic acid as epigenetic cancer drug: preclinical, clinical and transcriptional effects on solid tumors. Cancer Treat Rev, 34, 3, 206-222. https://doi.org/10.1016/j.ctrv.2007.11.003

5. Hubaux R., Vandermeers F., Crisanti M.C., Kapoor V., Burny A., Mascaux C., Albelda S.M., Willems L. (2010). Preclinical evidence for a beneficial impact of valproate on the response of small cell lung cancer to first-line chemotherapy. Eur J Cancer, 46, 9, 1724-1734. https://doi.org/10.1016/j.ejca.2010.03.021

6. Jafri S.H., Glass J., Shi R., Zhang S., Prince M., Kleiner-Hancock H. (2010). Thymoquinone and cisplatin as a therapeutic combination in lung cancer: In vitro and in vivo. J Exp Clin Cancer Res, 29, 87.

https://doi.org/10.1186/1756-9966-29-87

7. Kaufmann O., Georgi T., Dietel M. (1997). Utility of 123C3 monoclonal antibody against CD56 (NCAM) for the diagnosis of small cell carcinomas on paraffin sections. Hum Pathol, 28, 12, 1373-1378.

https://doi.org/10.1016/S0046-8177(97)90226-4

8. Korngold L., Lipari R. (1955). Tissue antigens of human tumors grown in rats, hamsters, and eggs. Cancer Res, 15, 3, 159-161.

9. Kunzi-Rapp K., Genze F., Küfer R., Reich E., Hautmann R.E., Gschwend J.E. (2001). Chorioallantoic membrane assay: vascularized 3-dimensional cell culture system for human prostate cancer cells as an animal substitute model. J Urol, 166, 4, 1502-1507. https://doi.org/10.1097/00005392-200110000-00081

10. Lee C.Y., Lai H.Y., Chiu A., Chan S.H., Hsiao L.P., Lee S.T. (2016). The effects of antiepileptic drugs on the growth of glioblastoma cell lines. J Neurooncol, 127, 3, 445-453. https://doi.org/10.1007/s11060-016-2056-6

11. Michaelis M., Michaelis U.R., Fleming I., Suhan T., Cinatl J., Blaheta R.A., Hoffmann K., Kotchetkov R., Busse R., Nau H., Cinatl J. Jr. (2004). Valproic acid inhibits angiogenesis in vitro and in vivo. Mol Pharmacol, 65, 3, 520-527. https://doi.org/10.1124/mol.65.3.520 
12. Nowak-Sliwinska P., Segura T., Iruela-Arispe M.L. (2014). The chicken chorioallantoic membrane model in biology, medicine and bioengineering. Angiogenesis, 17, 4, 779-804. https://doi.org/10.1007/s10456-014-9440-7

13. Nowak-Sliwinska P., van Beijnum J.R., van Berkel M., van den Bergh H., Griffioen A.W. (2010). Vascular regrowth following photodynamic therapy in the chicken embryo chorioallantoic membrane. Angiogenesis, 13, 4, 281-292. https://doi.org/10.1007/s10456-010-9185-x

14. Osuka S., Takano S., Watanabe S., Ishikawa E., Yamamoto T., Matsumura A. (2012). Valproic acid inhibits angiogenesis in vitro and glioma angiogenesis in vivo in the brain. Neurol Med Chir (Tokyo), 52, 4, 186-193.

https://doi.org/10.2176/nmc.52.186

15. Platta C.S., Greenblatt D.Y., Kunnimalaiyaan M., Chen H. (2008). Valproic acid induces Notch1 signaling in small cell lung cancer cells. J Surg Res, 148, 1, 31-37. https://doi.org/10.1016/j.jss.2008.03.008

16. Ribatti D. (2014). The chick embryo chorioallantoic membrane as a model for tumor biology. Exp Cell Res, 328, 2, 314-324.

https://doi.org/10.1016/j.yexcr.2014.06.010

17. Salcido C.D., Larochelle A., Taylor B.J., Dunbar C.E., Varticovski L. (2010). Molecular characterisation of side population cells with cancer stem cell-like characteristics in small-cell lung cancer. Br J Cancer, 102, 11, 1636-1644. https://doi.org/10.1038/sj.bjc.6605668

18. Shoji M., Ninomiya I., Makino I., Kinoshita J., Nakamura K., Oyama K., Nakagawara H., Fujita H., Tajima H., Takamura H., Kitagawa H., Fushida S., Harada S., Fujimura T., Ohta T. (2012). Valproic acid, a histone deacetylase inhibitor, enhances radiosensitivity in esophageal squamous cell carcinoma. Int J Oncol, 40, 6, 2140-2146. https://doi.org/10.3892/ijo.2012.1416

19. Vargas A., Zeisser-Labouèbe M., Lange N., Gurny R., Delie F. (2007). The chick embryo and its chorioallantoic membrane (CAM) for the in vivo evaluation of drug delivery systems. Adv Drug Deliv Rev, 59, 11, 1162-1176.

https://doi.org/10.1016/j.addr.2007.04.019

20. Wang W.L., Healy M.E., Sattler M., Verma S., Lin J., Maulik G., Stiles C.D., Griffin J.D., Johnson B.E., Salgia R. (2000). Growth inhibition and modulation of kinase pathways of small cell lung cancer cell lines by the novel tyrosine kinase inhibitor STI 571. Oncogene, 19, 31, 3521-3528.

https://doi.org/10.1038/sj.onc.1203698

21. Wilson S.M., Chambers A.F. (2004). Experimental metastasis assays in the chick embryo. Curr Protoc Cell Biol, Chapter 19, Unit 196. https://doi.org/10.1002/0471143030.cb1906s21

22. Zhang L., Wang G., Wang L., Song C., Wang X., Kang J. (2011). Valproic acid inhibits prostate cancer cell migration by up-regulating E-cadherin expression. Pharmazie, 66, 8, 614-618. 
Address for correspondence:

Angelija Valančiūtè

Department of Histology and Embryology

Lithuanian University of Health Sciences

A. Mickeviciaus Str., LT-44307 Kaunas, Lithuania.

Phone: +37061334201

E-mail: angelija.valanciute@lsmuni.lt 